\title{
Nutrigenomic evaluation of garlic (Allium sativum) and holy basil (Ocimum sanctum) leaf powder supplementation on growth performance and immune characteristics in broilers
}

\author{
N. Sheoran ${ }^{1}$, R. Kumar ${ }^{1}$, A. Kumar ${ }^{2}$, K. Batra², S. Sihag ${ }^{1}$, S. Maan² and N. S. Maan ${ }^{1}$
}

1. Department of Animal Nutrition, College of Veterinary Sciences, LLR University of Veterinary and Animal Sciences, Hisar - 125 004, Haryana, India; 2. Department of Animal Biotechnology, College of Veterinary Sciences, LLR University of Veterinary and Animal Sciences, Hisar - 125 004, Haryana, India.

Corresponding author: N. S. Maan, e-mail: narendermaan108@gmail.com, NS: sheorannancy@gmail.com,RK: drrakeshjaipur@gmail.com, AK: amankumar34237@gmail.com, KB: drkanishtbatra@gmail.com, SS: sihagsajjan54@gmail.com, SM: sushilamaan105@gmail.com Received: 31-08-2016, Accepted: 28-12-2016, Published online: 27-01-2017

doi: 10.14202/vetworld.2017.121-129 How to cite this article: Sheoran N, Kumar R, Kumar A, Batra K, Sihag S, Maan S, Maan NS (2017) Nutrigenomic evaluation of garlic (Allium sativum) and holy basil (Ocimum sanctum) leaf powder supplementation on growth performance and immune characteristics in broilers, Veterinary World, 10(1): 121-129.

\begin{abstract}
Aim: In this study, a planned research work was conducted to investigate the nutrigenomic aspects of supplementation of Allium sativum (garlic) and Ocimum sanctum (holy basil) leaf powder on the growth performance and immune characteristics of broilers.

Materials and Methods: A 6 weeks feeding trial was conducted with 280-day-old Ven Cobb broilers, distributed randomly into seven experimental groups. Each treatment had 4 replicates with 10 birds each. The birds of the control group $\left(\mathrm{T}_{1}\right)$ were fed a basal diet formulated as per BIS standards. The broilers of treatment groups $\mathrm{T}_{2}$ and $\mathrm{T}_{3}$ were fed basal diet supplemented with the commercially available garlic powder (GP) at levels of $0.5 \%$ and $1.0 \%$ of the feed, respectively, while broilers in $\mathrm{T}_{4}$ and $\mathrm{T}_{5}$ were fed basal diet supplemented with commercial grade holy basil leaf powder (HBLP) at levels $0.5 \%$ and $1.0 \%$ of the feed, respectively. Birds in the $\mathrm{T}_{6}$ were fed with $0.5 \% \mathrm{GP}$ and $0.5 \% \mathrm{HBLP}$, whereas $\mathrm{T}_{7}$ was fed with $1.0 \%$ GP and $1.0 \%$ HBLP. At the end of the feeding trial ( $6^{\text {th }}$ week $)$, blood samples were collected and analyzed for relative mRNA expression of toll-like receptors (TLR) 2, TLR 4 and TLR 7 using real-time polymerase chain reaction.
\end{abstract}

Results: The mean body weight gain and feed conversion efficiency were improved $(\mathrm{p}<0.05)$ in broilers fed the GP and HBLP incorporated diets compared with the control group. The relative mRNA expression levels of TLR 2, TLR 4 and TLR 7 in the peripheral blood of the broilers were found to be increased $(p<0.05)$ in the birds supplemented with graded levels of the GP and HBLP as compared to the untreated group.

Conclusion: The present work concludes that the inclusion of GP and HBLP could enhance the production performance and immune status of birds by augmenting the T-cell mediated immune response and thereby protects them from disease without decreasing growth traits as a possible substitution to conventional antimicrobials.

Keywords: broilers, garlic, gene expression, holy basil, toll-like receptors.

\section{Introduction}

Since time immemorial, traditional plants and their products, phytobiotics have been serving as an indispensable source of medicine in indigenous poultry production systems [1]. Today, around the globe, there is an increasing awareness about the emerging drug-resistant microbes, antimicrobial side effects and toxic residual effects of drugs in animal meat products which necessitate the search for newer feed alternatives or complementary medicines for the gut health maintenance and immunomodulation $[2,3]$. Therefore, the inherent utility of the indigenous herbal extracts/phytobiotics - such as Allium sativum (garlic),

Copyright: Sheoran, et al. Open Access. This article is distributed under the terms of the Creative Commons Attribution 4.0 International License (http://creativecommons.org/licenses/ by/4.0/), which permits unrestricted use, distribution, and reproduction in any medium, provided you give appropriate credit to the original author(s) and the source, provide a link to the Creative Commons license, and indicate if changes were made. The Creative Commons Public Domain Dedication waiver (http:// creativecommons.org/publicdomain/zero/1.0/) applies to the data made available in this article, unless otherwise stated.
Ocimum sanctum (tulsi), Curcuma longa, Azadirachta indica, and Withania somnifera - are being searched out for the practical applications in poultry system for improving health and production indicating toward their immense therapeutic ability [4,5]. In the recent decade, there has been a vigorous emphasis on improving the growth and production performance in broiler industry which has adversely affected the immunological status of the broiler birds. This has thereby, altered the host defense mechanism by encountering the prevailing microbes such as bacteria, fungi, pathogenic viruses, endo and ecto-parasites, and several harmful toxins. Hence, researchers are now thinking toward the use of an array of antimicrobials of the herbal origin which have shown to possess multiple immunomodulatory actions such as phagocytosis, modulation of immunoglobulin and cytokine secretion, cellular co-receptor expression, class switching, lymphocyte expression, and histamine release [4].

Conventional herbal medicinal plants have been claimed to modulate the immune response, thereby 
augmenting non-specific immunity, essentially macrophages, granulocytes, natural killer cells and many complement functions [6,7]. Phytobiotics from herbs by acting as immunomodulators, serve as a potential alternative for the conventional chemotherapy in a variety of challenges by enhancing the natural defense mechanisms of the host. Several plant extracts, compounds, and formulations have also been patented including various polysaccharides, lectins, flavonoids, peptides, and tannins which are used in various in vitro models to assess their immune response [8]. The herbal preparations such as GP and HBLP have tremendous potential in improving the cell mediated immunity in poultry birds thereby benefiting the poultry sector immensely.

In the present experiment, we have investigated whether the A. sativum (garlic powder [GP]) and $O$. sanctum (holy basil leaf powder [HBLP]) incorporated diets, in compliance with maintaining growth and production performance could increase the relative mRNA expression of toll-like receptors (TLR 2, TLR 4 and TLR 7) thus enhance immunological status of the broilers by modulating their immune response.

\section{Materials and Methods}

Ethical approval

The animal experiment was conducted in accordance with guidelines approved by the Institutional Animal Ethics Committee, 12/CPCSEA Dated 8.4.2013 in the Department of Animal Nutrition, Lala Lajpat Rai University of Veterinary and Animal Sciences, Hisar.

\section{Birds, experiment design, and management}

A total of 280-day-old commercial broiler chicks (Ven Cobb) maintained for a period of 6-week in the Department of Animal nutrition, were randomly allotted to 1 of 7 treatments in a completely randomized design. Each treatment consisted of 4 replicate pens with 10 chicks in each. The birds of the control group $\left(T_{1}\right)$ were fed a basal diet formulated as per BIS standards [9] meeting the requirements of the growing phase. The ingredient and chemical composition of the basal diet as analyzed according to the standards laid down by Association of Official Analytical Chemists(AOAC) [10] and is presented in Table-1. Seven dietary treatments included the basal diet $\left(\mathrm{T}_{1}\right)$ which acted as control group. The basal diets supplemented with $0.5 \%$ and $1.0 \%$ of the commercially available garlic powder (GP) in treatment groups $T_{2}$ and $\mathrm{T}_{3}$, respectively. Whereas, the birds in the treatment groups $\mathrm{T}_{4}$ and $\mathrm{T}_{5}$ were fed at $0.5 \%$ and $1.0 \%$ of the commercial grade HBLP, respectively. Birds in the treatment group $\mathrm{T}_{6}$ was fed with $0.5 \%$ GP and $0.5 \%$ HBLP, whereas $\mathrm{T}_{7}$ treatment group was fed with $1.0 \%$ GP and 1.0\% HBLP. The experimental design is presented in Table-2. The basal diets were formulated to meet the requirements for growing phase of the broilers as per the standards recommended by the Bureau of Indian Standards (BIS) (Table-1) [9]. All the herbal preparations used in the present experiment were
Table-1: Ingredient (\%) and chemical composition (\% dry matter [DM] basis) of basal diet.

\begin{tabular}{lcc}
\hline Item & $\begin{array}{c}\text { Starter } \\
\text { diet }\end{array}$ & $\begin{array}{c}\text { Finisher } \\
\text { diet }\end{array}$ \\
\hline Ingredient composition (\%) & & \\
Maize & 53 & 57 \\
Soybean meal & 19 & 16 \\
Rice police & 3 & 4 \\
Ground nut cake & 12 & 11 \\
Fish meal & 7 & 5 \\
Soybean oil & 4 & 5 \\
Mineral mixture & 2.0 & 2.0 \\
*Feed additives & 0.29 & 0.29 \\
Chemical composition (\% DM basis) & & \\
Crude protein & 22.04 & 20.08 \\
Crude fiber & 3.61 & 3.32 \\
Ether extract & 8.38 & 8.98 \\
Total ash & 6.18 & 5.86 \\
**Metabolizable energy (kcal/kg) & 3056 & 3163 \\
\hline *Feed addives include Vitamin mixture
\end{tabular}

*Feed additives include Vitamin mixture-I - $10 \mathrm{~g}$, vitamin, amino acid and Ca mixture-II - $20 \mathrm{~g}$, coccidiostat (Dinitro-0-yoluamide) - $50 \mathrm{~g}$, choline chloride - $50 \mathrm{~g}$, Lysine $-50 \mathrm{~g}$, DL- methionine - $80 \mathrm{~g}$ and chlortetracycline $-33.5 \mathrm{~g} / 100 \mathrm{~kg}$; **Calculated values - BIS (2007)

purchased from the local market. Floor litter system was followed where the chicks were kept hygienically in separate pens. All the birds were reared adopting uniform management conditions. The chicks were brooded at $35^{\circ} \mathrm{C}$ during the $1^{\text {st }}$ week and thereafter the temperature was reduced by $3^{\circ} \mathrm{C}$ every week until the temperature reached $25^{\circ} \mathrm{C} \pm 1^{\circ} \mathrm{C}$. The birds were vaccinated against prevailing diseases adopting a standard protocol. Individual body weight of chicks was recorded at 0 day age and thereafter weekly. Total feed consumed, growth rate, and feed conversion ratio (FCR) were calculated and presented in Table-2. At the end of the experiment, one bird from each replicate was slaughtered ethically by mechanical stunning followed by exsanguinities. Different carcass parameters - such as dressed weight (g), eviscerated weight (g), non-edible weight (g), and drawn weight $(\mathrm{g})$ - were calculated and depicted in Table-3.

\section{Blood collection and analysis}

At the end of the feeding trial ( $6^{\text {th }}$ week $)$, blood samples were collected from one broiler per replicate, making four samples per treatment and thus a total of 28 samples were analyzed. About $2 \mathrm{ml}$ of blood was collected from each bird via brachial wing vein puncture using sterilized syringes and $5 \mathrm{ml}$ scalp vein needle set into vacutainer containing ethylene diamine tetraacetic acid (EDTA) for TLR mRNA expression. Plasma was prepared by centrifuging the blood at $3000 \mathrm{rpm}$ for $10 \mathrm{~min}$. The plasma was then transferred into a microcentrifuge tube using a Pasteur pipette and stored at $-20^{\circ} \mathrm{C}$ until further analysis.

\section{Reverse transcription (cDNA synthesis); RNA extraction and preparation of CDNA \\ Total RNA was isolated from blood samples by using TRIzol ${ }^{\circledR}$ as per the manufacturer's instruction.}


In brief, $1 \mathrm{ml}$ of TRIzol ${ }^{\circledR}$ reagent, $200 \mu \mathrm{l}$ of chloroform was added to $600 \mathrm{ul}$ of blood followed by centrifugation for phase separation and precipitation with isopropanol. Total RNA extracted was dissolved in $30 \mu \mathrm{L}$ NFW and quantified using Qubit ${ }^{\circledR} 2.0$ fluorometer (Invitrogen). Reverse transcription was carried out with total reaction volume of $20 \mu \mathrm{L}$ using cDNA synthesis kit (Fermentas). Briefly, NFW (7.00 $\mu \mathrm{L}), 5 \mathrm{X}$ RT buffer $(4 \mu \mathrm{L}), 10 \mathrm{mM}$ dNTPs (Fermentas) $(2 \mu \mathrm{L})$, total RNA $(5 \mu \mathrm{L})$, RT $200 \mathrm{IU} / \mu \mathrm{L}(1 \mu \mathrm{L})$, Random hexamer $(1 \mu \mathrm{L})$. The polymerase chain reaction (RT-PCR) cyclic conditions were as initial incubation at $25^{\circ} \mathrm{C}$ for $5 \mathrm{~min}$, reverse transcription at $42^{\circ} \mathrm{C}$ for $1 \mathrm{~h}$, and deactivation at $70^{\circ} \mathrm{C}$ for $5 \mathrm{~min}$ in thermal cycler (Applied Biosystem). The cDNA was stored at $-20^{\circ} \mathrm{C}$ till further use.

\section{Real time PCR}

For the analysis of temporal expression profile of different genes, real-time PCR was carried out using
Step I plus real-time PCR system. For the real-time PCR reaction, SYBR Green dye based PCR mastermix (Affymetrix) was used, and all the instructions were followed as per the manufacturer. The reaction for the target gene, TLRs (TLR 2, TLR 4, and TLR 7), and the endogenous control, $\beta$-actin gene was carried out in triplicate along with non-template control as a negative control for each sample. The reaction mixture used to carry out the real-time PCR reaction for TLRs 2, 4 and 7 ; and $\beta$-actin gene contains $2 X$ SYBR green PCR mastermix (Affymetrix, $12.5 \mu \mathrm{L}$ ), primers (forward and reverse $0.3 \mathrm{M}$ each), NFW (variable), and template $(2 \mu \mathrm{L})$. The cyclic conditions used for amplification were according to the instructions of the manufacturer. Amplification was done with denaturation for $15 \mathrm{~min}$ at $95^{\circ} \mathrm{C}$, followed by 40 cycles of denaturation for $5 \mathrm{~s}$ at $95^{\circ} \mathrm{C}$, and annealing/elongation for $30 \mathrm{~s}$ at $60^{\circ} \mathrm{C}$, and a final melting curve analysis. The set of primers used for the real-time PCR is as shown in Table-4.

Table-2: Experimental design.

\begin{tabular}{|c|c|c|c|c|}
\hline $\begin{array}{l}\text { Treatment } \\
\text { groups }\end{array}$ & Particulars & $\begin{array}{l}\text { Number of } \\
\text { replicates }\end{array}$ & Number of birds/replicate & Total \\
\hline $\mathrm{T}_{1}$ & $\begin{array}{l}\text { Control-standard broiler diet as per BIS (2007) } \\
\text { specifications }\end{array}$ & 4 & 10 & 40 \\
\hline $\mathrm{T}_{2}$ & Control+5 g garlic powder/kg of diet & 4 & 10 & 40 \\
\hline $\mathrm{T}_{3}^{2}$ & Control+10 g garlic powder/kg of diet & 4 & 10 & 40 \\
\hline $\mathrm{T}_{4}^{3}$ & Control+5 g holy basil leaf powder/kg of diet & 4 & 10 & 40 \\
\hline $\mathrm{T}_{5}^{4}$ & Control+10 g holy basil leaf powder/kg of diet & 4 & 10 & 40 \\
\hline $\mathrm{T}_{6}^{5}$ & $\begin{array}{l}\text { Control }+5 \mathrm{~g} \text { garlic powder } / \mathrm{kg} \text { of diet }+5 \mathrm{~g} \text { holy } \\
\text { basil powder } / \mathrm{kg} \text { of diet }\end{array}$ & 4 & 10 & 40 \\
\hline \multirow[t]{2}{*}{$\mathrm{T}_{7}$} & $\begin{array}{l}\text { Control }+10 \mathrm{~g} \text { garlic powder } / \mathrm{kg} \text { of diet }+10 \mathrm{~g} \text { holy } \\
\text { basil powder } / \mathrm{kg} \text { of diet }\end{array}$ & 4 & 10 & 40 \\
\hline & & & Total & 280 \\
\hline
\end{tabular}

Table-3: Performance parameters viz. feed intake ( $\mathrm{g} / \mathrm{bird})$, body weight gain $(\mathrm{g} / \mathrm{bird})$ and FCR in broilers under different dietary treatments during overall period of 6 weeks of experiment.

\begin{tabular}{lccr}
\hline Treatments & Feed intake (g/bird) & Body weight gain (g/bird) & FCR \\
\hline $\mathrm{T}_{1}$ & $3771.75 \pm 4.23$ & $1801.75^{\mathrm{a}} \pm 1.79$ & $2.09^{\mathrm{c}} \pm 0.01$ \\
$\mathrm{~T}_{2}$ & $3713.25 \pm 11.94$ & $1823.00^{\mathrm{ab}} \pm 21.17$ & $2.03^{\mathrm{bc}} \pm 0.02$ \\
$\mathrm{~T}_{3}$ & $3687.25 \pm 79.93$ & $1873.50^{\mathrm{b}} \pm 9.13$ & $1.96^{\mathrm{b}} \pm 0.03$ \\
$\mathrm{~T}_{4}$ & $3645.75 \pm 61.90$ & $1818.50^{\mathrm{b}} \pm 11.92$ & $2.00^{\mathrm{bc}} \pm 0.03$ \\
$\mathrm{~T}_{5}$ & $3634.25 \pm 17.80$ & $1863.25^{\mathrm{b}} \pm 8.41$ & $1.95^{\mathrm{b}} \pm 0.01$ \\
$\mathrm{~T}_{6}$ & $3627.50 \pm 6.64$ & $2129.25^{\mathrm{c}} \pm 22.83$ & $1.70^{\mathrm{a}} \pm 0.01$ \\
$\mathrm{~T}_{7}$ & $3640.25 \pm 4.23$ & $2094.75^{\mathrm{c}} \pm 32.93$ & $1.73^{\mathrm{a}} \pm 0.04$ \\
\hline
\end{tabular}

$a, b, c$ Mean values bearing different superscripts in a column differ significantly $(p<0.05) ; T_{1}$ : Basal diet, $T_{2}: 0.5 \%$ garlic powder, $T_{3}: 1 \%$ garlic powder, $T_{4}: 0.5 \%$ tulsi leaf powder, $T_{5}: 1 \%$ tulsi leaf powder, $T_{6}$ : Mixture of garlic powder and tulsi leaf powder at $0.5 \%$ each, $\mathrm{T}_{7}$ : Mixture of garlic powder and tulsi leaf powder at $1 \%$ each, $\mathrm{FCR}=$ Feed conversion ratio

Table-4: Oligonucleotide sequences of sense and antisense primers for real-time PCR products determined.

\begin{tabular}{|c|c|c|c|c|}
\hline Gene $^{1}$ & Primer & Primer sequence $^{2}$ & Accession No. & Product size \\
\hline \multirow[t]{2}{*}{$\beta$-Actin } & Sense & 5'-GAGAAATTGTGCGTGACATCA-3' & L08165 & 152 \\
\hline & Antisense & 5'-CCTGAACCTCTCATTGCCA-3' & & \\
\hline \multirow[t]{2}{*}{ TLR 2} & Sense & 5'-CATTCACCATGAGGCAGGGATAG-3' & AB046533 & 157 \\
\hline & Antisense & 5'-GGTGCAGATCAAGGACACTAGGA-3' & & \\
\hline \multirow[t]{2}{*}{ TLR 4} & Sense & 5'-TTCAGAACGGACTCTTGAGTGG-3' & AY064697 & 131 \\
\hline & Antisense & 5'-CAACCGAATAGTGGTGACGTTG-3' & & \\
\hline \multirow[t]{2}{*}{ TLR 7} & Sense & 5'-TTGCTGCTGTTGTCTTGAGTGAG-3' & AJ627563 & 182 \\
\hline & Antisense & 5'-AACAACAGTGCATTTGACGTCCT-3' & & \\
\hline
\end{tabular}

${ }^{1}$ TLR 2=Toll-like receptor 2; TLR 4=Toll-like receptor 4; TLR 7=Toll-like receptor 7. ${ }^{2}$ Primers for toll-like receptors and $\beta$-actin were described by Sato et al. [27] and Bai et al. [28], respectively 
Relative quantification by comparative $C_{T}$ method ( $\Delta \Delta C_{T}$ method)

The average $\mathrm{C}_{\mathrm{T}}$ (Threshold cycle) value obtained for the TLRs 2, 4 and 7 (target) gene was normalized to $\beta$-actin (endogenous control). The data obtained were subjected to comparative $\mathrm{C}_{\mathrm{T}}$ method [11] for the analysis of the expression levels of targeted TLR gene and an endogenous control. The sample at $26 \mathrm{~h}$ of incubation was selected as calibrator.

\section{Sequencing of product}

Amplicons were sequenced using the Big Dye Terminator Cycle Sequencing Kit (Applied Biosystems, Carlsbad, CA, USA) on an automatic ABI 3130 xl Genetic Analyzer (Applied Biosystems, Carlsbad, CA, USA). The sequence obtained shows $100 \%$ nucleotide identity with the TLR sequence of chicken available in the global database.

\section{Statistical analysis}

Data were analyzed by one-way ANOVA as a completely randomized design using the General Linear Model (GLM) procedure of SAS Institute. Individual cage was used as an experimental unit for analyzing the performance data, whereas each bird selected was used as the statistical unit for analyzing the data of gene expression. Differences among means were tested by the least significant difference method, and $p<0.05$ was considered to be statistically significant group.

\section{Results}

\section{Growth performance and FCR}

Data pertaining to the growth performance as depicted in Table- 3 revealed that significantly $(p<0.05)$ highest mean body weight gain was observed in the treatment groups $\mathrm{T}_{6}$ and $\mathrm{T}_{7}$ where birds were supplemented a combination of GP and HBLP at $0.5 \mathrm{~g}$ and $1.0 \mathrm{~g} / \mathrm{kg}$ of the diet, respectively. It was then followed by treatment groups $\mathrm{T}_{3}$ and $\mathrm{T}_{5}$ in which hens were fed ration supplemented with GP and HBLP at higher levels of inclusion of $1.0 \mathrm{~g} / \mathrm{kg}$ of feed, respectively. While, the control group $\mathrm{T}_{1}$ recorded lowest mean body weight gain among all the treatments at all age groups. No significant difference in body weight gain was observed among the dietary treatments $T_{1} T_{2}$, and $\mathrm{T}_{4}$. However, no significant $(\mathrm{p}<0.05)$ difference in feed intake $(\mathrm{g} / \mathrm{bird})$ was observed between dietary treatment groups $\mathrm{T}_{2}, \mathrm{~T}_{3}, \mathrm{~T}_{4}, \mathrm{~T}_{5}, \mathrm{~T}_{6}$ and $\mathrm{T}_{7}$ as compared to the control group $\mathrm{T}_{1}$ over the entire period of the experiment (Table-3).

The current research work on the FCR as shown in Table-3 unveiled that FCR was found to be significantly $(\mathrm{p}<0.05)$ improved in $\mathrm{T}_{6}$ and $\mathrm{T}_{7}$ as compared to control group $\mathrm{T}_{1}$ due to dietary supplementation of GP and HBLP in combination at $0.5 \%$ and $1.0 \%$ of the feed, respectively. Similarly, significantly improved FCR was observed in $T_{3}$ and $T_{5}$ treatment groups where GP and HBLP were included in the diet of hens at $1.0 \%$ of the ration, respectively. However, no significant difference was observed among supplemental groups $\mathrm{T}_{2}$ and $\mathrm{T}_{4}$ compared to $\mathrm{T}_{1}$ (control).

The study results as depicted in Table-5 revealed that overall with respect to the whole period of experiment there was significant $(\mathrm{p}<0.05)$ increase in the carcass parameters, viz., dressed weight (g), eviscerated weight $(\mathrm{g})$ and drawn weight $(\mathrm{g})$ in treatment groups $\mathrm{T}_{3} \mathrm{~T}_{6}$ and $\mathrm{T}_{7}$, in which broilers were supplemented with GP either alone or in combination with HBLP. While no significant difference was observed on the non-edible weight (g) due dietary supplementation of either of the herbal products (GP and HBLP).

\section{TLR mRNA gene expression of broilers}

The differential expression level of TLRs, viz. TLR 2, TLR 4 and TLR 7 gene transcripts in the of Ven Cobb commercial broiler strains was studied by relative quantification method. The level of target mRNA in different treatment groups was determined by comparative $\mathrm{C}_{\mathrm{t}}$ method $\left(\Delta \Delta \mathrm{C}_{\mathrm{t}}\right.$ method). The nutrigenomic expression analysis as presented in Table- 6 and also depicted in Figures- 1 and 2 revealed that relative mRNA expression of TLR 2 of broilers was found to be $(\mathrm{p}<0.05)$ enhanced in the treatment groups $\mathrm{T}_{4}$ and $\mathrm{T}_{5}$ supplemented with $0.5 \%$ and $1 \%$ of the HBLP fed individually or in combination with similar levels of garlic powder in treatment groups $\mathrm{T}_{6}$ and $\mathrm{T}_{7}$, respectively. While, as presented in Table- 6 and shown in Figures- 1 and 2 at the end of the 6 weeks of experimental protocol broilers had $(p<0.05)$ higher relative mRNA expression of TLR 4 in the plasma of broilers fed diet supplemented with $0.5 \%$ and $1 \%$ of the HBLP in the treatment groups $\mathrm{T}_{4}$ and $\mathrm{T}_{5}$, respectively. Furthermore, the relative TLR 4 mRNA expression

Table-5: Carcass parameters viz. dressed weight $(\mathrm{g})$, eviscerated weight ( $\mathrm{g})$, non-edible weight $(\mathrm{g})$ and drawn weight $(\mathrm{g})$ in broilers under different treatments.

\begin{tabular}{lcccc}
\hline Treatments & Dressed weight $(\mathbf{g})$ & Eviscerated weight (g) & Non-edible weight (g) & Drawn weight (g) \\
\hline $\mathrm{T}_{1}$ & $1284.85^{\mathrm{a}} \pm 7.84$ & $1071.59^{\mathrm{a}} \pm 5.41$ & $503.75 \pm 2.12$ & $1108.07^{\mathrm{a}} \pm 6.43$ \\
$\mathrm{~T}_{2}$ & $1326.42^{\mathrm{a}} \pm 19.97$ & $1093.38^{\mathrm{ab}} \pm 21.25$ & $452.97 \pm 1.59$ & $1189.50^{\mathrm{a}} \pm 18.49$ \\
$\mathrm{~T}_{3}$ & $1395.67^{\mathrm{b}} \pm 8.39$ & $1170.62^{\mathrm{b}} \pm 7.99$ & $519.62 \pm 2.79$ & $1264.05^{\mathrm{b}} \pm 10.39$ \\
$\mathrm{~T}_{4}$ & $1301.25^{\mathrm{b}} \pm 13.65$ & $1095.64^{\mathrm{ab}} \pm 12.96$ & $510.23 \pm 1.73$ & $1187.84^{\mathrm{ab}} \pm 9.49$ \\
$\mathrm{~T}_{5}$ & $1366.23^{\mathrm{b}} \pm 10.24$ & $1159.87^{\mathrm{ab}} \pm 9.37$ & $484.89 \pm 0.94$ & $1254.89^{\mathrm{b}} \pm 14.83$ \\
$\mathrm{~T}_{6}$ & $1613.48^{\mathrm{c}} \pm 20.98$ & $1367.78^{\mathrm{c}} \pm 23.74$ & $521.64 \pm 2.46$ & $1478.33^{\mathrm{c}} \pm 18.99$ \\
$\mathrm{~T}_{7}$ & $1573.85^{\mathrm{c}} \pm 35.24$ & $1335.40^{\mathrm{c}} \pm 31.48$ & $516.21 \pm 1.94$ & $1443.91^{\mathrm{c}} \pm 25.31$ \\
\hline
\end{tabular}

$a, b, c$ Mean values bearing different superscripts in a column differ significantly $(p<0.05) ; T_{1}$ : Basal diet, $T_{2}: 0.5 \%$ garlic powder, $\mathrm{T}_{3}: 1 \%$ garlic powder, $\mathrm{T}_{4}: 0.5 \%$ tulsi leaf powder, $\mathrm{T}_{5}: 1 \%$ tulsi leaf powder, $\mathrm{T}_{6}$ : Mixture of garlic powder and tulsi leaf powder at $0.5 \%$ each, $\mathrm{T}_{7}$ : Mixture of garlic powder and tulsi leaf powder at $1 \%$ each 


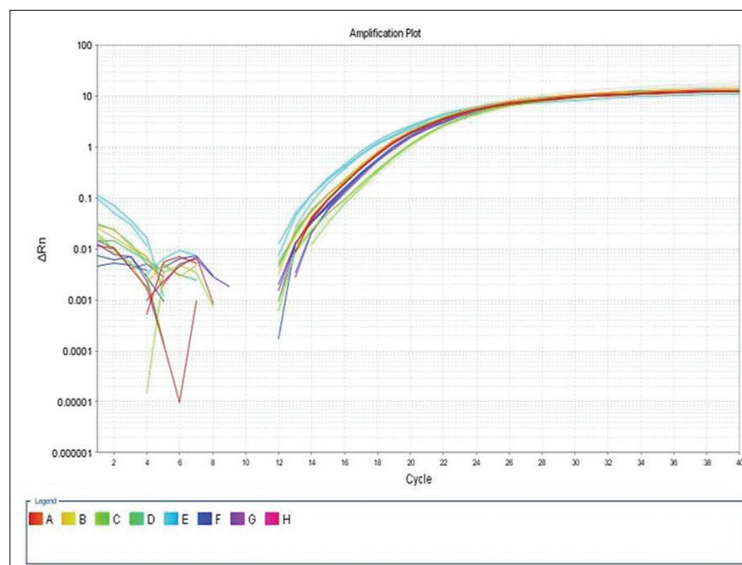

A
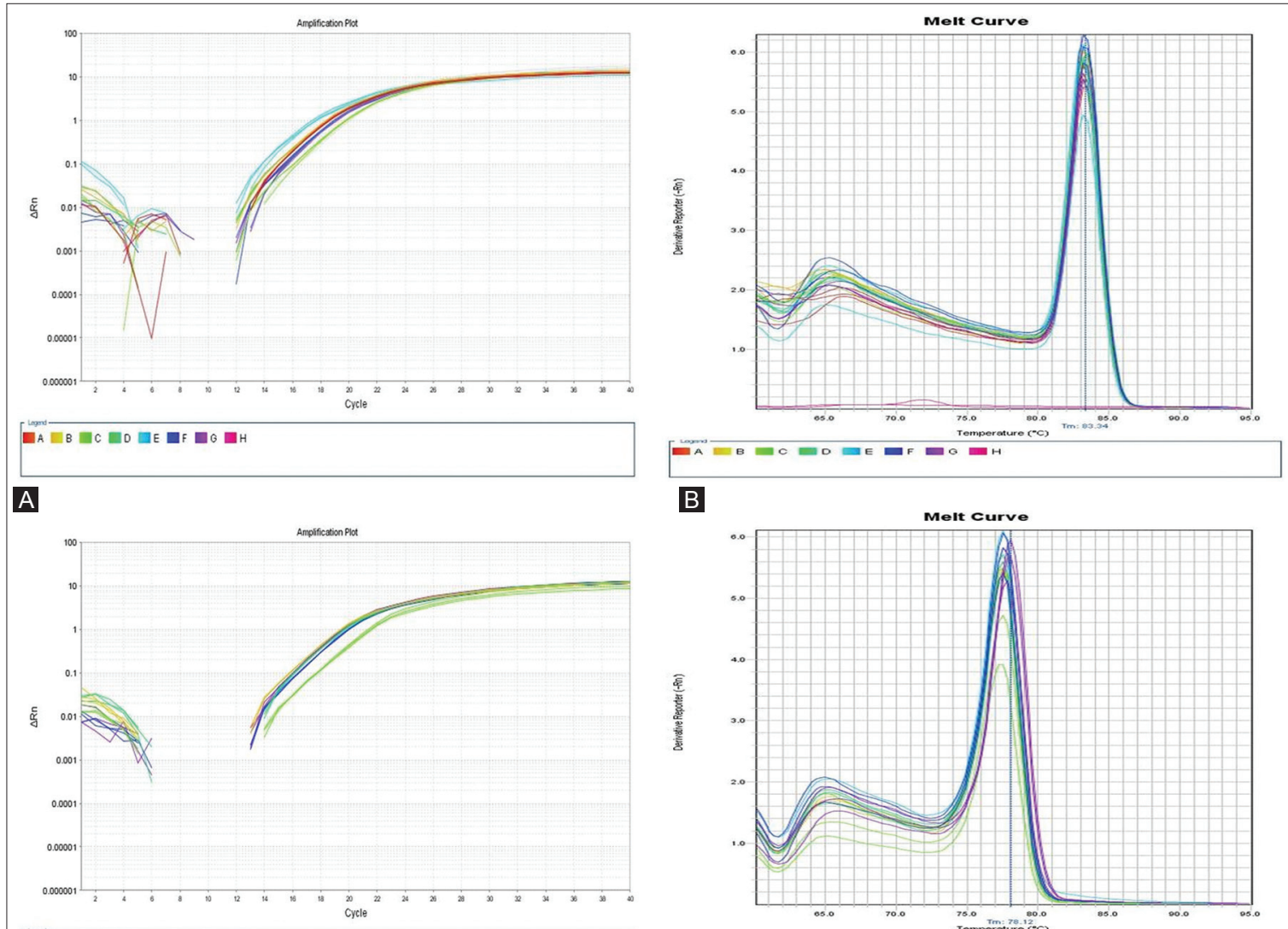

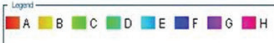

B

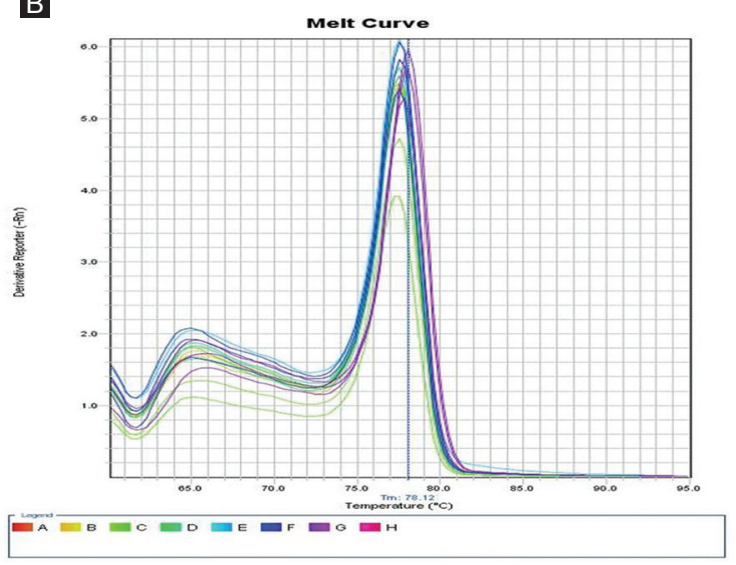

D

C

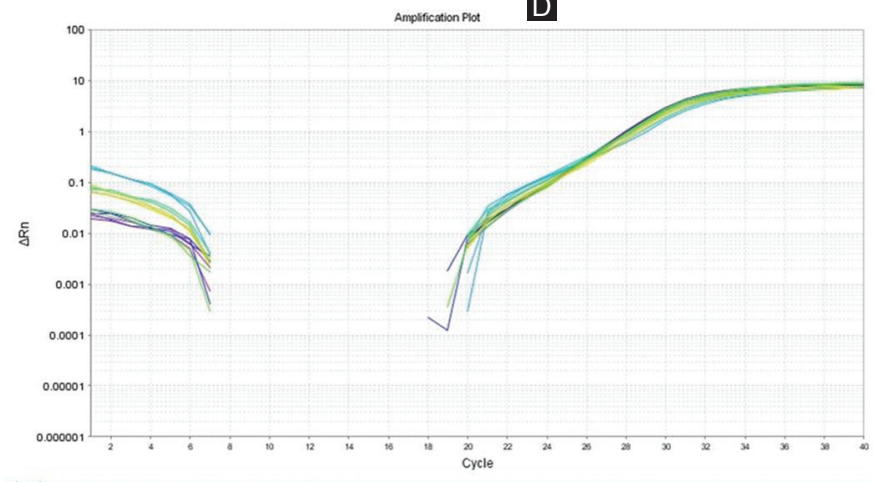

\section{$\left[\begin{array}{l}\operatorname{loph} \\ \mathrm{B}\end{array}\right.$}

E

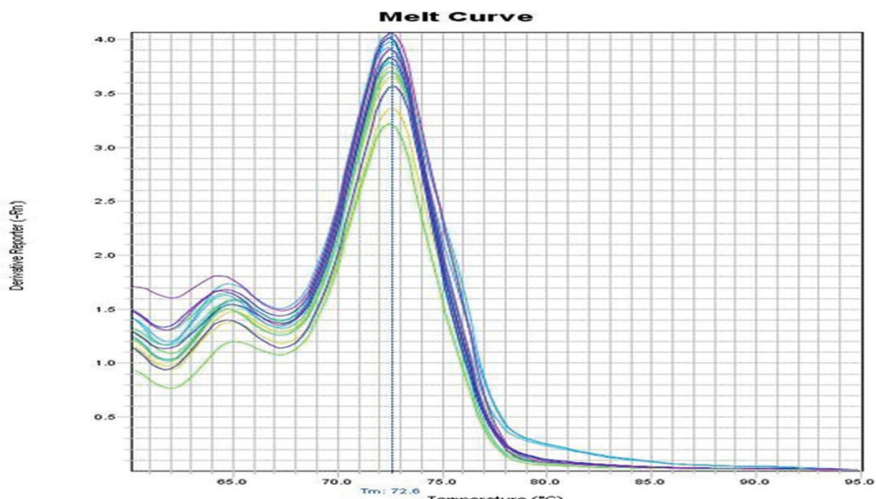

F

Figure-1: Amplification plot and melt curve for chicken toll-like receptors (TLR 2), TLR 4 and TLR 7. Panel A and B Amplification plot and melt curve for chicken TLRs 2. Panel C and D Amplification plot and melt curve for chicken TLRs 4. Panel $\mathrm{E}$ and $\mathrm{F}$ Amplification plot and melt curve for chicken TLRs 7. 


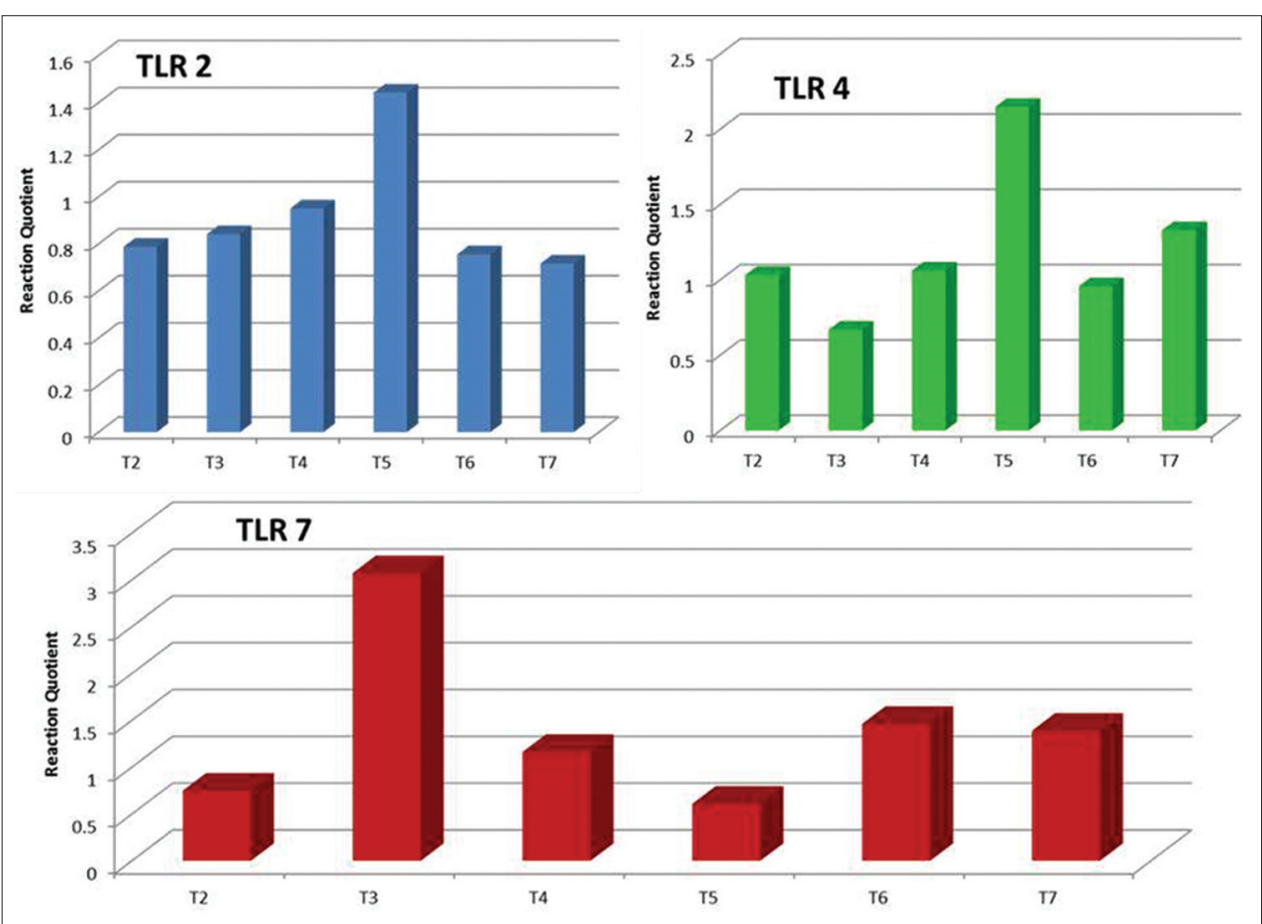

Figure-2: Effect of supplementation of garlic and holy basil leaf powder on relative mRNA expression of toll-like receptors 2 (TLR 2), TLR 4 and TLR 7 in the plasma of broilers. Significantly highest level of increase in the mRNA expression of TLR 2 and TLR 4 was observed in the treatment group $T_{5}$. While, significantly highest increase in the mRNA expression of TLR 7 was observed in the treatment group $T_{3}$ where broilers were fed garlic powder (GP) at $1 \%$ of the diet followed by the birds in the treatments groups $\mathrm{T}_{6}$ and $\mathrm{T}_{7}$ fed with increasing levels of $0.5 \%$ and $1 \%$ of the GP and holy basil leaf powder in combination, respectively.

Table-6: Relative quantitation expression analysis of the toll-like receptors (TLR 2, TLR 4 and TLR 7) with reference to the endogenous reference gene $B$ actin.

\begin{tabular}{|c|c|c|c|c|c|c|}
\hline $\begin{array}{l}\text { Sample } \\
\text { name }\end{array}$ & $\begin{array}{l}\text { Target } \\
\text { Name }\end{array}$ & Ст & Ст Mean & Cт SD & $\begin{array}{c}\Delta C T \\
\text { mean }\end{array}$ & $\mathbf{R Q}$ \\
\hline T1 & TLR 2 & 16.567 & $16.544^{c}$ & 0.0297 & -2.801 & 1.000 \\
\hline T2 & & 16.455 & $16.387^{b}$ & 0.0591 & -2.457 & 0.787 \\
\hline T3 & & 17.838 & $17.759^{e}$ & 0.0695 & -2.552 & 0.841 \\
\hline T4 & & 16.409 & $16.476^{\mathrm{bc}}$ & 0.1109 & -2.728 & 0.950 \\
\hline T5 & & 15.560 & $15.408^{\mathrm{a}}$ & 0.1409 & -3.330 & 1.443 \\
\hline T6 & & 17.029 & $16.958^{d}$ & 0.0723 & -2.396 & 0.755 \\
\hline T7 & & 17.125 & $17.097^{\mathrm{cd}}$ & 0.0248 & -2.320 & 0.716 \\
\hline T1 & TLR 4 & 18.563 & $18.5541^{\mathrm{e}}$ & 0.0201 & -0.791 & 1.000 \\
\hline T2 & & 17.995 & $18.009^{b}$ & 0.0261 & -0.834 & 1.030 \\
\hline T3 & & 20.110 & $20.104^{f}$ & 0.1091 & -0.206 & 0.666 \\
\hline T4 & & 18.336 & $18.329^{d}$ & 0.0199 & -0.875 & 1.060 \\
\hline T5 & & 16.827 & $16.846^{\mathrm{a}}$ & 0.0811 & -1.893 & 2.146 \\
\hline T6 & & 18.587 & $18.630^{\mathrm{e}}$ & 0.0420 & -0.724 & 0.954 \\
\hline T7 & & 18.201 & $18.217^{c}$ & 0.0631 & -1.200 & 1.327 \\
\hline T1 & TLR 7 & 28.603 & $28.811^{c d}$ & 0.1825 & 9.4658 & 1.000 \\
\hline T2 & & 28.506 & $28.727^{\mathrm{bcd}}$ & 0.2148 & 9.8828 & 0.749 \\
\hline T3 & & 27.854 & $28.158^{\mathrm{a}}$ & 0.2643 & 7.8472 & 3.070 \\
\hline T4 & & 28.352 & $28.454^{\mathrm{abcd}}$ & 0.0901 & 9.2500 & 1.161 \\
\hline T5 & & 28.557 & $28.920^{d}$ & 0.3323 & 10.180 & 0.609 \\
\hline T6 & & 28.373 & $28.274^{\mathrm{ab}}$ & 0.0860 & 8.9186 & 1.461 \\
\hline T7 & & 28.093 & $28.409^{a b c}$ & 0.4489 & 8.9919 & 1.388 \\
\hline
\end{tabular}

$\mathrm{a}, \mathrm{b}, \mathrm{c}, \mathrm{d}, \mathrm{e}, \mathrm{f}$ Mean values bearing different superscripts in a column differ significantly $(p<0.05)$. TLR=Toll-like receptors

was found to be significantly higher in the treatment groups $\mathrm{T}_{6}$ and $\mathrm{T}_{7}$ where the birds were fed a combination of GP and HBLP at $0.5 \%$ and $1 \%$ in their diet, respectively. While no significant effect was observed in the relative mRNA expression of TLR 4 in the birds supplemented with $0.5 \%$ and $1 \%$ of the garlic powder in the treatment groups $\mathrm{T}_{2}$ and $\mathrm{T}_{3}$, respectively as compared to that of birds fed maize based basal diet in control $\mathrm{T}_{1}$ and other dietary treatments. However, the data pertaining to the relative mRNA levels of TLR 7 (Table-6) and shown in Figures-1 and 2 in the plasma of birds revealed slightly different pattern of expression and it was found that significantly highest levels of expression was observed in treatment group $\mathrm{T}_{3}$ supplemented at $1 \%$ of the garlic powder, followed by the treatment groups $\mathrm{T}_{6}$ and $\mathrm{T}_{7}$ in which the broilers were fed a combination of GP and HBLP at $0.5 \%$ and $1 \%$ of their ration, respectively. While no significant differences were observed in the experimental groups $\mathrm{T}_{2}, \mathrm{~T}_{4}$ and $\mathrm{T}_{5}$ as compared to the control group and rest of the supplemental groups. However, treatment groups $\mathrm{T}_{6}$ and $\mathrm{T}_{7}$ did not show any significant $(\mathrm{p}<0.05)$ differences among themselves. In nutshell, experimental treatments containing GP and HBLP either alone or in their combination in the broiler's diet have potent immune modulating activity by showing stimulatory effect on relative mRNA expression of TLR 2, TLR 4 and TLR 7 of the commercial broilers.

\section{Discussion}

Beneficial effects of bioactive plant substances in animal nutrition may include the stimulation of appetite and feed intake, the improvement of endogenous digestive enzyme secretion, activation of immune responses and antibacterial, antiviral and antioxidant actions [12]. Thus, all the nutrients are directed toward 
growth promotion resulting in enhanced growth performance. The findings of the current work reported a significant $(p<0.05)$ positive effect on average body weight gain by the supplementation of graded levels of the GP and HBLP either alone or in their combinations in commercial broilers at 2, 4 and 6 weeks of age. The improvement in weight gain of the birds using garlic in their rations may probably be due to the fact that allicin (an antibiotic substance found in garlic), inhibits growth of intestinal bacteria such as Staphylococcus aureus and Escherichia coli and inhibit aflatoxins producing fungi $[13,14]$. Resultantly, when the load of these bacteria in the intestine is low, birds may absorb more nutrients, leading to the improvement in weight gain of the birds using rations supplemented with $A$. sativum.

The basil plant possessing antioxidant properties results in increase in the digestive enzymes and decrease in bacterial activities and thus leading to muscle weight gain in broiler chicks [15]. Even the improvement in live body weight in broilers may be due to antibacterial effects related to garlic derivative propylpropane thiosulfonate (PTSO) that led to modulation of normal intestinal microflora by competitive exclusion and antagonism and thus improved nutrients digestibility in growing broilers $[13,16]$.

The present investigation revealed that broilers supplemented with GP and HBLP at various levels and in their combinations led to utilization of their feed more efficiently than the birds fed ration without addition. The antibacterial properties of these herbal supplements resulted in better absorption of the nutrients present in the gut, finally leading to improved FCR. It can thus be concluded that there was significant positive effect on the average body weight and subsequent enhanced FCR due to supplementation of the diet with herbal products, GP and HBLP either individually or in combinations in the commercial broiler strains.

Medicinal herbs have shown to possess multiple immunomodulatory actions like phagocytosis, modulation of immunoglobulin and cytokine secretion, cellular co-receptor expression, class switching, lymphocyte expression, and histamine release [4]. In current work, it was observed that dietary inclusion of GP and HBLP either alone or in combination significantly increased the relative mRNA expression of TLR cell markers, which confirmed that these herbal feed additives could stimulate the T cell immune system in the plasma of broiler birds.

In the present investigation, we found that there was a significant increase in the relative mRNA expression of TLR 2 and TLR 4 in the plasma of the broilers fed diet supplemented with graded levels of the HBLP either alone or in combination with garlic powder. TLR 2 recognizes a variety of microbial components. These include lipoproteins/lipopeptides from various pathogens, peptidoglycan and lipoteichoic acid from Gram-positive bacteria [17]. TLR 4 is the principal receptor for lipopolysaccharide, which is a major component of outer membrane of gram-negative bacteria [18]. Several studies have shown that the essential oils and biologically active compounds in fresh leaves of $O$. sanctum are effective against bacteria such as E. coli, Shigella spp. Salmonella typhi, and Pseudomonas aeruginosa [19].

The antimicrobial action of essential oils in O. sanctum (Linn.) is attributed to monoterpene components which are mostly phenolic in nature. They exert membrane damaging effects to microbial strains and stimulate leakage of cellular potassium which is responsible for a lethal action related to cytoplasmic membrane damage [20]. Immunostimulant potential of 'Tulsi' is helpful in the treatment of immunosuppression. It shows its immunomodulatory effect by increase in interferon- $\gamma$, interleukin-4, T-helper cells, NK cells [21] thus reducing total bacterial count, increasing neutrophil and lymphocyte count and enhancing phagocytic activity and phagocytic index. Oil from 'Tulsi' seed can mediate GABAergic pathways and by this it can modulate both humoral and cell-mediated immunity [22]. Antimicrobial effects of basil essential oil could also be owed to the higher concentrations of linalool and eugenol [23]. Another study revealed that the ethanol and methanol extracts of $O$. sanctum had the ability to inhibit the growth of all test bacteria including E. coli and P. aeruginosa [24]. Herbs can influence selectively the microorganism by an antimicrobial activity thus favors better nutrient utilization and absorption or the stimulation of the immune system [25].

From the above reported studies and our result findings, it can be inferred that, supplementation of diet with 1\% HBLP and GP improved performance, as holy basil leaf might have suppressed the growth of harmful organisms like Coliforms, thereby creating a conducive environment for the growth of the beneficial microbes like Lactobacillus, Bifidobacteria spp. and thereby, aid in digestion and give better performance. Similar mechanism of action would have occurred while supplementing GP and HBLP in combination at $0.5 \%$ and $1 \%$ dose level. Result findings related to the relative mRNA gene expression of TLR 2 and TLR 4 in the present study it can be inferred that HBLP given at $1 \%$ of feed showed better results as compared to the GP fed at $1 \%$ of the feed.

TLR 7 family is implicated in intracellular recognition of nucleic acids. The TLR 7 recognizes some antiviral compounds and single-stranded viral RNA. In this study, supplementation of diet with garlic powder either individually or in combination with HBLP significantly increased the relative mRNA expression of TLR 7 in the plasma of the broiler birds. Researchers are focusing on an extract of A. sativum called Ajoene, which appears to protect $\mathrm{CD}+$ cells from attack by HIV early in the viral life cycle. Allicin present in the A. sativum can protect against plasmodium infection by enhancing the host innate as well as innate immunity [26]. Tulsi or holy basil is suggested to shorten the course of illness, 
clinical symptoms in patients suffering from viral hepatitis and also enhances survival of viral encephalitis patients. Based on the above discussion and our present research work, it can be concluded that GP and HBLP both individually or in combination possess potent antiviral properties reflected by the increased expression of TLR 7 in the plasma of the broilers.

\section{Conclusions}

Conventional medicinal herbs constitute an important aspect of applied biotechnological research and therefore as opposed to antimicrobial drugs and chemotherapeutic agents it can be employed for growth promotion and immunity booster in commercial broiler production systems. To summarize, the results of this study may lead us to conclude that the addition of GP and HBLP at higher level of $1 \%$ of the feed either alone or in combination in the diet of the broilers increased the relative mRNA expression of TLR 2, 4 and 7, although, among the two feed additives HBLP fed at $1 \%$ of diet was found to have better expression and production enhancing profile. Thus, the inclusion of the GP and HBLP could enhance the overall growth performance and immune status of birds by augmenting the $\mathrm{T}$ cell mediated immune response and thereby protects them from disease without decreasing performance traits.

\section{Authors' Contributions}

This study is the part of M.V.Sc. research work of the first author NS, who carried out the research under the guidance of Professor NSM. SM, AK and SS helped during the trial. The article was drafted by NS. The revision was made by KB, RK and SM. All authors have read and approved the final version of the manuscript.

\section{Acknowledgments}

Authors are thankful for the help and support received from Department of Animal Nutrition and Animal Genetics for their help in carrying out our research. Also, we want to extend our gratitude toward Department of Animal Biotechnology, for the lab facility, guidance and financial assistance received under the RKVY project RKVY project no. $4029 \mathrm{C}$ (g) AN-03 OA.

\section{Competing Interests}

The authors declare that they have no competing interests.

\section{References}

1. Gopi, M., Karthik, K., Manjunathachar, H.V., Tamilmahan, P. and Kesavan, M. (2014) Essential oils as a feed additive in poultry nutrition. Adv. Anim. Vet. Sci., 2: 1-7.

2. Chauhan, R.S. (2010) Nutrition, immunity and livestock health. Indian Cow Sci. Econ. J., 7: 2-13.

3. Chakraborty, S. and Pal, S.K. (2012) Plants for cattle health: A review of ethnoveterinary herbs in veterinary health care. Ann. Ayurvedic Med., 1: 144-152.

4. Mahima, R.A., Deb, R., Latheef, S.K. and Samad, H.A. (2012) Immunomodulatory and therapeutic potentials of herbal, traditional/indigenous and ethnovetrinary medicines. Pak. J. Biol. Sci., 15: 754-774.

5. Sridhar, M., Suganthi, R.U. and Thammiaha, V. (2014) Effect of dietary resveratrol in ameliorating aflatoxin B1-induced changes in broiler birds. J. Anim. Physiol. Anim. Nutr., 99(6): 1094-1104.

6. Hashemi, S.R. and Davoodi, H. (2012) Herbal plants as new immunostimulator in poultry industry: A review. Asian $J$. Anim. Vet. Adv., 7: 105-116.

7. Mirzaei-Aghsaghali, A. (2012) Importance of medical herbs in animal feeding: A review. Ann. Biol. Res., 3: 918-923.

8. Cherng, J.M., Chiang, W. and Chiang, L.C. (2008) Immunomodulatory activities of common vegatables and spices of Umbelliferae and its related coumarins and flavonoids. Food Chem., 106: 944-950.

9. Bureau of Indian Standards, BIS. (2007) Requirement for Chicken Feeds. IS: 1374-2007. Bureau of Indian Standards, New Delhi.

10. AOAC. (2007) Official Methods of Analysis. 18 ${ }^{\text {th }}$ ed. Association of Official Analytical Chemists, Gaitherburg, Madison.

11. Livak, K.J. and Schmittgen, T.D. (2001) Analysis of relative gene expression data using real-time quantitative PCR and the 2(-Delta Delta C (T)) method. Methods, 25(4): 402-408.

12. Toghyani, M., Toghyani, M., Gheisari, A., Ghalamkari, G. and Eghbalsaied, S. (2011) Evaluation of cinnamon and garlic as antibiotic growth promoter substitutions on performance, immune responses, serum biochemical and haematological parameters in broiler chicks. Livest. Sci., 138: 167-173.

13. Amagase, H., Petesch, B.L., Matsuura, H., Kasuga, S. and Itakura, Y. (2001) Intake of garlic and its bioactive components. J. Nutr., 131: 955S-962S.

14. Meraj, I.C.A. (1998) Effect of Garlic and Neem Leaves Supplementation on the Performance of Broiler Chickens. M.Sc. Thesis, Deptartement of Poultry Sciences, University of Agriculture, Faisalabad, Pakistan.

15. Khan, F.U., Durrani, F.R., Sultan, A., Khan, R. and Naz, S. (2009) Effect of fenugreek (Trigonella foenum-graecum) seed extract on visceral organs of broiler chicks. ARPN J. Agric. Biol. Sci., 4: 58-61.

16. Peinado, M., Ruij, R., Echavarri, A., Aranda-Olmedo, I. and Rubio, L. (2013) Garlic erivative PTS-O modulates intestinal microbiota composition and improves digestibility in growing broiler chickens. Anim. Feed Sci. Technol., 181: 87-92.

17. Takeda, K. and Akira, S. (2005) Toll-like receptors in innate immunity. Int. Immunol., 17: 1-14.

18. Kannaki, T.R., Reddy, M.R., Verma, P.C. and Shanmugam, M. (2010) Chicken toll-like receptors and their role in immunity. World's Poult. Sci. Assoc., 66: 727-738.

19. Prakash, P. and Gupta, N. (2005) Therapeutic uses of Ocimum sanctum Linn (tulsi) with a note on eugenol and its pharmacological actions: A short review. Indian J. Physiol. Pharmacol. 49(2): 125-131.

20. Mahamood, K., Yaqoob, U. and Bajwa, R. (2008) Antibacterial activity of essential oil of Ocimum sanctum (L). Mycopath, 6: 63-65.

21. Mondal, S., Varma, S., Bamola, V.D., Naik, S.N. and Mirdha, B.R. (2011) Double-blinded randomized controlled trial for immunomodulatory effects of tulsi (Ocimum sanctum Linn.) Leaf extract on healthy volunteers. J. Ethnopharmacol., 136: 452-456.

22. Mediratta, P.K., Sharma, K.K. and Singh, S. (2002) Evaluation of immunomodulatory potential of Ocimum sanctum seed oil and its possible mechanism of action. J. Ethanopharmacol., 80: 15-20.

23. Verma, R.S., Bisht, P.S., Padalia, R.C., Saikia, D. and Chauhan, A. (2011) Chemical composition and antibacterial activity of essential oil from two Ocimum spp. Grown in sub-tropical India during spring-summer cropping season. Asian J. Tradit. Med., 6(5): 211-217. 
24. Pathmanathan, M.K., Uthayarasa, K., Jeyadevan, J.P. and Jeyaseelan, E.C. (2010) In vitro antibacterial activity and phytochemical analysis of some selected medicinal plants. Int. J. Pharm. Biol. Arch., 1(3): 291-299.

25. Wenk, C. (2003) Herbs and botanicals as feed additives in monogastric animals. Asian-Australas J. Anim. Sci., 16(2): 282-289.

26. Feng, Y., Zhu, X., Wang, Q., Jiang, Y., Shang, H., Cui, L. and Cao, Y. (2012) Allicin enhances proinflammatory immune responses and protects against acute murine malaria infection. Malar. J., 11: 268-296.

27. Sato, K., Takahashi, K., Tohno, M., Miura, Y., Kamada, T., Ikegami, S. and Kitazawa, H. (2009) Immunodulation in gut-associated lymphoid tissue of neonatal chicks by immunobiotic diets. Poult. Sci., 88: 2532-538.

28. Bai, S. P., Lu, L., Luo, X. G. and Liu, B. (2008) Kinetic of manganese absorption in ligated small intestinal segments of broilers. Poult. Sci., 87: 2596-2604.

$* * * * * * * *$ 